\title{
Exploitation of Gynoecious Lines in Cucumber (Cucumis Sativus L.) for Heterosis Breeding
}

\author{
Madhu Sharma ${ }^{1 \& 2}$, Yudhvir Singh ${ }^{1}$, Shailesh Kumar Singh ${ }^{2}$ and V. K. Dhangrah ${ }^{2 *}$
}

${ }^{1}$ Dept. of Vegetable Science and Floriculture, CSK Himachal Pradesh Krishi Vishvavidyalaya, Palampur, H.P. (176 062), India

${ }^{2}$ Dept. of Horticulture, School of Agriculture, Lovely Professional University, Phagwara, Punjab (144 411), India

\section{Article History}

Manuscript No. AR1557

Received in $10^{\text {th }}$ March, 2016

Received in revised form $30^{\text {th }}$ March, 2016

Accepted in final form $7^{\text {th }}$ April, 2016

\section{Correspondence to}

*E-mail: vinod.19505@1pu.co.in

\section{Keywords}

Cucumber, gynoecious lines, heterosis, fruit fly, powdery mildew

\begin{abstract}
Despite being native of India and having sufficient genetic variability, very meagre work has been done for the improvement of cucumber. To tide over the situation, there is a need to make concerted efforts to develop location specific hybrids having desirable horticultural and quality traits, and to make available their seeds to the farmers at a reasonable price. Moreover, cucumber crop is predominantly monoceious in nature but gynoecious sex form has also been reported that facilitates hybridization by reducing labour cost for crossing. Thus, to overcome the said problem; five gynoecious lines 'EC-5082, Plp-Gy-1, G-1, G-3 and PCUCP-4' and eleven testers 'KL-1, K-pap, Japanese Long Green, Poinsette, DPC-1, EC-173934, Summer Green, K-90, Sel75-2-10, K-75 and KL-3' were crossed to derive fifty five crosses. The crosses and parents along with 2 standard checks were evaluated at Palampur and Bajaura in Himachal Pradesh, India. The pooled analysis of variance over locations revealed significant differences due to location, genotype and location $\times$ genotype for all the characters. Significant range of heterobeltiosis and standard heterosis was recorded among crosses for all characters. As many as 50 cross over better parent, 42 cross over standard check 1 and 41 cross over standard check 2 exhibited positive heterosis for marketable yield vine ${ }^{-1}$. The cross $\mathrm{Plp} \times \mathrm{K}$-pap exhibited maximum positive heterosis over standard checks for marketable yield vine ${ }^{-1}$ and sufficient heterosis in desirable direction for yield components and traits related to earliness. Majority of the cross combinations succumb to fruit fly infestation and powdery mildew incidence. However, G-3×Sel-75-2-10 showed resistance against fruit fly infestation at both locations.
\end{abstract}

\section{Introduction}

Cucumber (Cucumis sativus L.) belongs to family Cucurbitaceae, which distributed throughout the warmer parts of the world (Gopala krishnan, 2007). This is commercially grown all over the world in open fields and small gardens, even under polyhouses or glasshouses. Cucumber fruit is characterized by low energy, high fiber and high water containing vegetable. Its immature fruits are known as good appetizer to have cooling effect. Cucumber is also a good source of Vitamin B and C, carbohydrates, calcium and phosphorus (Yawalkar, 1985). Cucumber is both a leading commercial crop and popular home garden vegetable in low and mid hills of the Himachal Pradesh and the fruits are available from April to October. The crop brings lucrative returns to the hill farmers during July to October, when it is not produced in the adjoining plains.

Breeding for higher yields is an important objective of cucumber breeding programmes (Wehner, 1987). Yield of cucumber can be improved through breeding to develop resistance against pest-diseases (Peterson, 1975); improvement in cultural practices (Cargill et al., 1975); qualitative traits improvements like gynoecious sex expression, colour of fruit and yield (Wehner, 1987) or development of high yielding varieties or hybrids. Moreover, cucumber crop is predominantly monoceious in nature but gynoecious sex form has also been reported (Pati et al., 2015) which facilitates hybridization by reducing labour cost for crossing. The gynoecious hybrid cultivars often bear a high proportion of female flowers, resulting in earliness, good yield and give many fruits in a single harvest. The first commercial $F_{1}$ hybrid of cucumber developed in India was 'Pusa Sanyog' which was released in 1973 by IARI, Katrain. Now-a-days, many hybrids of cucumber are being marketed by the private seed companies. However, the performance of Pusa Sanyog is confined to cooler and sub-tropical conditions (Dhilon, 2004). Later on Dr. Y.S. Parmar University of Horticulture and Forestry has also developed two hybrids KH-1 and KH-2 but they perform poorly under high rainfall areas.

To tide over the situation, there is a need to make concerted efforts to develop hybrids for wide adapability. Heterosis 
breeding has been utilized in many crops including cucurbits to exploit dominance variance (Cramer and Wehner, 1999). Being monoecious and cross-pollinated crop and having appreciable number of seeds fruit ${ }^{-1}$, it provides ample scope for the utility of hybrid vigour. Moreover, use of gynoecious lines in hybrid development will not only enhance the chances of getting high yielding hybrids but also reduce the cost of hybrid seed production drastically. Considering the significance of heterosis breeding involving gynoecious lines in cucumber (Cucumis sativus L.); an investigation was carried out to estimate the extent of heterosis for different yield contributing traits to find out the best heterotic combination for wider adaptability.

\section{Materials and Methods}

Five gynoecious lines of cucumber viz., EC-5082 (Regional Research Station, Indian Agriculture Research Institute, Katrain); Plp-Gy-1 (CSK HPKV, Palampur); G-1 and G-3 (Dr. Y.S. Parmar University of Horticulture and Forestry, Nauni, Solan); and PCUCP-4 (G.B. Pant University of Agriculture and Technology, Pantnagar, Utrakhand) were crossed with eleven testers viz., Japanese Long Green (Regional Research Station, Indian Agriculture Research Institute, Katrain), Poinsette (National Seeds Corporation, New Delhi); KL-1, K-Pap, DPC-1, EC-173934, Summer Green, Sel-75-2-10 and KL-3 (CSK HPKV, Palampur); and K-95 and K-75 (Dr. Y.S. Parmar University of Horticulture and Forestry, Nauni, Solan) in Line $\times$ Tester model at Palampur, Himachal Pradesh, India during summer season of 2007 and 2008. As a result $55 \mathrm{~F}_{1}$ progenies were obtained which were evaluated at two locations Palampur and Bajaura along with 16 parents and 2 standard checks Pusa Sanyog and Solan Khira Hybrid-1 during summer season of 2009. The experiements were carried out in Completely Randomized Block Design with three replications. The crop was grown at a spacing of $1.5 \mathrm{~m}$ between rows and $0.5 \mathrm{~m}$ between plants.

Observations were recorded for different quantitive characters from five competitive plants in each entry and replication. The characters studied were vine length (m), number of primary branches plant ${ }^{-1}$, days to first female flower appearance, nodal position of first female flower, days to first picking, fruit length $(\mathrm{cm})$, fruit girth $(\mathrm{cm})$, average fruit weight $(\mathrm{g})$, number of marketable fruits vine ${ }^{-1}$, marketable yield vine ${ }^{-1}(\mathrm{~kg})$, harvest duration (days) and total soluble solids (\%). The data recorded on above characters were analyzed as per the design for working out pooled analysis of variance over locations (Gomez and Gomez, 1984). Heterosis over better parent and two standards checks was estimated from pooled data using methods of Turner (1953); Hayes et al. (1956). The genotypes were characterized with respone to incidence of fruit fly (\%) and powdery mildew disease (\%) as followed by Nath (1966); Sen and Kapoor (1974), respectively.

\section{Results and Discussion}

The analysis of variances (Table 1) revealed that location had significant effect on performance of all characters except nodal position of first female flower. Significant differences among genotypes for all characters indicated presence of sufficient genetic variability in the experimental genetic material. Significant interactions (location $\times$ genotypes) for all the characters indicated the possibility of selection of heterotic hybrids for growing at both locations.

\begin{tabular}{|c|c|c|c|c|c|}
\hline $\begin{array}{l}\text { Sources of variation } \\
\text { (D.F.) Character }\end{array}$ & $\begin{array}{l}\text { Location } \\
\text { (1) }\end{array}$ & $\begin{array}{c}\text { Replication } \\
\text { (4) }\end{array}$ & $\begin{array}{c}\text { Genotype } \\
(72) \\
\end{array}$ & $\begin{array}{c}\text { Location } \times \text { Genotype } \\
(72)\end{array}$ & $\begin{array}{c}\text { Pooled Error } \\
\quad(288)\end{array}$ \\
\hline Vine length (m) & $2.666^{*}$ & 0.004 & $0.251^{*}$ & $0.082^{*}$ & 0.003 \\
\hline Number of primary branches & $31.725^{*}$ & 0.076 & $0.443^{*}$ & $0.311^{*}$ & 0.059 \\
\hline Days to first female flower appearance & $423.780^{*}$ & 0.106 & $38.495^{*}$ & $6.028^{*}$ & 0.231 \\
\hline Nodal position of first female flower & 0.002 & 0.193 & $7.158^{*}$ & $0.530^{*}$ & 0.087 \\
\hline Days taken to first picking & $143.313^{*}$ & 0.447 & $70.958^{*}$ & $7.697^{*}$ & 0.311 \\
\hline Fruit length $(\mathrm{cm})$ & $1068.242^{*}$ & 0.280 & $47.766^{*}$ & $3.029^{*}$ & 0.311 \\
\hline Fruit girth $(\mathrm{cm})$ & $65.424^{*}$ & 0.050 & $1.244^{*}$ & $0.043^{*}$ & 0.020 \\
\hline Average fruit weight (g) & 77904.000* & 2.385 & $3061.648^{*}$ & $650.537^{*}$ & 9.698 \\
\hline Marketable fruits vine ${ }^{-1}$ & $298.602^{*}$ & 0.069 & $23.513^{*}$ & $2.423^{*}$ & 0.036 \\
\hline Marketable yield vine ${ }^{-1}(\mathrm{~kg})$ & $42.042^{*}$ & 0.002 & $1.633^{*}$ & $0.203^{*}$ & 0.001 \\
\hline Harvest duration & $7473.625^{*}$ & 1.132 & $96.293^{*}$ & $35.850^{*}$ & 0.237 \\
\hline Total soluble solids $(\%)$ & $0.747^{*}$ & 0.005 & $0.269^{*}$ & $0.098^{*}$ & 0.012 \\
\hline
\end{tabular}

"Significant at $5 \%$ level of significance 


\subsection{Heterosis for growth traits}

Increased vine length is desirable attribute to obtain significant marketable yield for longer duration. Heterosis for vine length (Table 2) ranged from -8.08 to $11.26 \%$ over better parent (BP), -8.18 to $10.78 \%$ over standard check 1 (SC1) and -9.85 to $8.76 \%$ over standard check 2 (SC2). Of 55 crossess, 24 cross exhibited positive heterosis over better parent, 42 cross over standard check 1 and 36 crosses over standard check 2 . Cucumber plants with more vine length and primary branches produce more fruits plant ${ }^{-1}$ in a unit area with lesser planting densities. Many crosses which exhibited positive heterosis for vine length, also showed hybrid vigour for the primary branches vine ${ }^{-1}$ (Table 2). Among 55 crosses, heterosis for number of primary branches vine ${ }^{-1}$ ranged from -11.55 to $26.67 \%$ over better parent, -5.32 to $32.89 \%$ over standard check 1 and -8.06 to $29.03 \%$ over standard check 2 . Thirty six crosses exhibited positive better parent heterosis whereas 52 cross over standard check 1 and 49 cross combinations over standard check 2 . The present findings are in consonance with the findings of Bairagi et al. (2002); Singh and Sharma (2006).

\subsection{Heterosis for earliness}

Earliness is one of the most desirable trait for commercial vegetable production to fetch high market price for agricultural produce. In cucumber, days to first female flower appearance (Miller and Quisenberry, 1976), nodal position of first female flower (El-Shawaf and Baker, 1981) and days taken to first picking are considered as good indices of earliness. Hence heterosis in the negative direction is desirable for these traits and data presented in Table 2. The heterosis for first female flower appearance ranged from -9.98 to $9.28 \%$ over better parent, -12.98 to $6.23 \%$ over standard check 1 and -12.37 to $6.97 \%$ over standard check 2 , respectively. Of 55 crosses, fourteen crosses over better parent, thirty six crosses over standard check 1 and thirty one crosses over standard check 2 exhibited negative heterosis. Heterosis for nodal position of first female flower ranged from -10.06 to $34.23 \%$ over better parent, -13.41 to $16.62 \%$ over standard check 1 and -15.14 to $14.29 \%$ over standard check 2 . The comparison of crosses revealed that only one cross had negative heterosis over better parent whereas fourteen crosses over standard check 1 and sixteen crosses over standard check 2 exhibited heterosis in same direction.

Early maturing strains are of immense value in capturing early markets. Hence, for days taken to first fruit picking also, the interest of the breeder lies in the search of combinations having negative heterosis. The magnitude of heterosis for days to first fruit picking (Table 2) ranged from - 10.00 to 15.99 over better parent, -9.77 to $13.20 \%$ over standard check 1 and -12.20 to $10.15 \%$ standard check 2 . Significant negative heterosis was recorded in 13 cross over better parent, 18 cross over standard check 1 and 21 cross over standard check 2 .

With regard to days to first female flower, ample number of hybrids showed their superiority over better parent, standard check 1 and 2, which may be attributed to the fact that all the hybrid combinations in the present study have been produced form gynoecious $\times$ monoecious parents. Gynoecious lines are said to be early in maturity than the normal monoecious types (Peterson, 1960) and thus ensure early picking. For nodal position of first female flower, only few hybrids exhibited superiority over better parent because of the fact that the better parent here are pure gynoecious lines but pretty good number of hybrids were found superior over standard check 1 and standard check 2 . The perusal of heterotic values over locations revealed that the combinations G- $1 \times \mathrm{K}$-pap and PCUCP-4×JLG had appreciable tendency for early maturity of fruits. This may be on account of early female flower and attainment of lower nodal position by the female flower which led to early development of fruits in these crosses. The findings in the present study with respect to earliness are in close agreement with many researchers (Bairagi et al., 2002; Sudhakhar et al., 2005; Yadav et al., 2008).

\subsection{Heterosis for yield and quality}

The data pertainig to heterosis among 55 crosses for yield and contributing traits is presented in Table 2. Length and girth regulate the size of fruit for enhancing market acceptability. Generally positive heterosis is desirable for these traits. Range of heterosis and Heterosis Heterosis for fruit length ranged from -44.21 to $22.71 \%$ over better parent, 2.58 to $84.93 \%$ over standard check 1 and -7.47 to $66.82 \%$ over standard 2 . Seventeen crosses exhibited positive heterosis over better parent while in comparison with standard check 1 and standard check 2,54 crosses and 47 crosses had positive heterotic effect, respectively. The heterosis for fruit girth ranged from -25.93 to $14.08 \%$ over better parent, -13.22 to $34.57 \%$ over standard check 1 and -14.32 to $32.87 \%$ over standard check 2 . Twelve crosses exhibited positive heterosis over better parent, 40 crosses over standard check 1 and 37 over standard check 2 . Thus a number of cross combinations exhibited significant positive heterosis for fruit size (fruit length and fruit girth) over better parent as well as standard checks. The present findings are in conformity with Bairagi et al. (2002); Sudhakar et al. (2005); Singh and Sharma (2006); Yadav et al. (2008).

Average fruit weight is one of the most important traits, which directly contributes towards yield. The magnitude of heterosis for this trait ranged from -18.86 to $27.92 \%$ over better parent, $-21.86 \%$ to $24.89 \%$ over standard check 1 and -24.53 to $20.63 \%$ over standard check 2 . As many as 31 cross had significant positive heterosis over their respective better parent, 34 cross 
over standard check 1 and 27 cross over standard check 2. Yield in cucumber is dependent primarily on fruit number Bairagi et al. (2002); Sudhakhar et al. (2005); Singh and and fruit weight (Saikia et al., 1995; Bairagi et al., 2002). Sharma (2006); Yadav et al. (2008) have also reported positive The latter, however is a function of time, which is under the heterosis for this trait. control of grower. The magnitude of heterosis for marketable

Table 2: Heterotic effects of crosses for different characters

\begin{tabular}{|c|c|c|c|c|c|c|}
\hline \multirow[t]{2}{*}{ Character } & \multirow{2}{*}{$\begin{array}{c}\text { Heterotic } \\
\text { effects } \\
\text { over }\end{array}$} & \multirow{2}{*}{$\begin{array}{c}\text { Range of } \\
\text { heterosis \% }\end{array}$} & \multirow{2}{*}{$\begin{array}{c}\text { Number of } \\
\text { heterotic } \\
\text { crosses }\end{array}$} & \multicolumn{3}{|c|}{ Heterosis $\%$ of three superior crosses } \\
\hline & & & & Plp $\times$ K-pap & G-3×Sel-75-2-10 & G-1×K-pap \\
\hline \multirow[t]{3}{*}{ Vine length } & $\mathrm{BP}$ & -8.08 to 1126 & 24 & $9.61^{* *}$ & $4.48^{* *}$ & $11.18^{* *}$ \\
\hline & $\mathrm{SC} 1$ & -8.18 to 10.78 & 42 & $3.90^{* *}$ & $4.09^{* *}$ & $5.39^{* *}$ \\
\hline & $\mathrm{SC} 2$ & -9.85 to 8.76 & 36 & $2.01^{* *}$ & $2.19^{* *}$ & $3.47^{* *}$ \\
\hline \multirow[t]{3}{*}{ Number of primary branches vine ${ }^{-1}$} & $\mathrm{BP}$ & -11.55 to 26.67 & 36 & $18.30^{* *}$ & $6.15^{* *}$ & $18.61^{* *}$ \\
\hline & $\mathrm{SC} 1$ & -5.32 to 32.89 & 52 & $24.58^{* *}$ & $26.25^{* *}$ & $24.92^{* *}$ \\
\hline & $\mathrm{SC} 2$ & -8.06 to 29.03 & 49 & $20.97^{* *}$ & $22.58^{* *}$ & $21.29^{* *}$ \\
\hline \multirow[t]{3}{*}{ Days to first female flower appearance } & $\mathrm{BP}$ & -9.98 to 9.28 & 14 & $-6.38^{* *}$ & $-2.94^{*}$ & $-3.83^{* *}$ \\
\hline & $\mathrm{SC} 1$ & -12.98 to 6.23 & 36 & $-10.20^{* *}$ & $-6.90^{* *}$ & $-12.98^{* *}$ \\
\hline & $\mathrm{SC} 2$ & -12.37 to 6.97 & 31 & $-9.58^{* *}$ & $-6.25^{* *}$ & $-12.37^{* *}$ \\
\hline \multirow[t]{3}{*}{ Nodal position of first female flower } & $\mathrm{BP}$ & -10.06 to 34.23 & 01 & 1.01 & 0.67 & $-10.06^{*}$ \\
\hline & $\mathrm{SC} 1$ & -13.41 to 16.62 & 14 & $-12.54^{*}$ & $-12.54^{*}$ & -12.68 \\
\hline & $\mathrm{SC} 2$ & -15.14 to 14.29 & 16 & $-14.29^{* *}$ & $-14.30^{* *}$ & $-14.43^{* *}$ \\
\hline \multirow[t]{3}{*}{ Days to first fruit picking } & $\mathrm{BP}$ & -10.00 to 15.99 & 13 & -1.33 & -0.87 & $-7.52^{* *}$ \\
\hline & $\mathrm{SC} 1$ & -9.77 to 13.20 & 08 & $-6.53^{* *}$ & $-3.26^{* *}$ & $-9.77^{* *}$ \\
\hline & $\mathrm{SC} 2$ & -12.20 to 10.15 & 21 & $-9.04^{* *}$ & $-5.86^{* *}$ & $-12.20^{* *}$ \\
\hline \multirow[t]{3}{*}{ Fruit length } & $\mathrm{BP}$ & -44.21 to 22.71 & 17 & 1.89 & $14.89^{* *}$ & $14.70^{* *}$ \\
\hline & $\mathrm{SC} 1$ & 2.58 to 8.93 & 54 & $35.86^{* *}$ & $14.60^{* *}$ & $36.14^{* *}$ \\
\hline & $\mathrm{SC} 2$ & -7.47 to 66.82 & 47 & $22.55^{* *}$ & $3.38^{*}$ & $22.80^{* *}$ \\
\hline \multirow[t]{3}{*}{ Fruit girth } & $\mathrm{BP}$ & -25.93 to 14.08 & 12 & 2.16 & $3.68^{* *}$ & $-10.11^{* *}$ \\
\hline & $\mathrm{SC} 1$ & -13.22 to 34.57 & 40 & $21.19^{* *}$ & $28.02^{* *}$ & $6.63^{* *}$ \\
\hline & $\mathrm{SC} 2$ & -14.32 to 32.87 & 37 & $19.66^{* *}$ & $26.41^{* *}$ & $5.29^{* *}$ \\
\hline \multirow[t]{3}{*}{ Average fruit weight } & $\mathrm{BP}$ & -18.86 to 27.92 & 31 & $19.88^{* *}$ & $5.47^{* *}$ & $27.92^{* *}$ \\
\hline & $\mathrm{SC} 1$ & -21.86 to 24.89 & 34 & $22.02^{* *}$ & $8.84^{* *}$ & $18.80^{* *}$ \\
\hline & $\mathrm{SC} 2$ & -24.53 to 20.63 & 27 & $17.85^{* *}$ & $5.12^{* *}$ & $14.74^{* *}$ \\
\hline \multirow[t]{3}{*}{ Marketable fruits vine ${ }^{-1}$} & $\mathrm{BP}$ & -1.42 to 72.50 & 52 & $42.43^{* *}$ & $69.42^{* *}$ & $41.51^{* *}$ \\
\hline & $\mathrm{SC} 1$ & -5.57 to 65.35 & 45 & $49.73^{* *}$ & $51.87^{* *}$ & $47.22^{* *}$ \\
\hline & $\mathrm{SC} 2$ & -2.42 to 70.75 & 50 & $54.62^{* *}$ & $56.83^{* *}$ & $52.03^{* *}$ \\
\hline \multirow[t]{3}{*}{ Marketable yield vine ${ }^{-1}$} & $\mathrm{BP}$ & -6.97 to 91.63 & 50 & $79.91^{* *}$ & $81.69^{* *}$ & $80.51^{* *}$ \\
\hline & $\mathrm{SC} 1$ & -14.21 to 79.91 & 42 & $79.91^{* *}$ & $66.55^{* *}$ & $64.46^{* *}$ \\
\hline & $\mathrm{SC} 2$ & -15.15 to 77.94 & 41 & $77.94^{* *}$ & $64.72^{* *}$ & $62.65^{* *}$ \\
\hline \multirow[t]{3}{*}{ Harvest duration } & $\mathrm{BP}$ & -18.89 to 15.59 & 33 & $8.11^{* *}$ & $8.98^{* *}$ & $5.15^{* *}$ \\
\hline & $\mathrm{SC} 1$ & -10.31 to 24.67 & 40 & $16.60^{* *}$ & $16.65^{* *}$ & $13.41^{* *}$ \\
\hline & $\mathrm{SC} 2$ & -6.58 to 29.85 & 43 & $21.45^{* *}$ & $21.50^{* *}$ & $18.12^{* *}$ \\
\hline \multirow[t]{3}{*}{ Total soluble solids } & $\mathrm{BP}$ & -11.40 to 25.29 & 29 & -1.11 & $-4.46^{*}$ & -3.70 \\
\hline & $\mathrm{SC} 1$ & -9.39 to 19.05 & 40 & $5.95^{*}$ & $16.27^{* *}$ & 3.17 \\
\hline & $\mathrm{SC} 2$ & -13.18 to 14.07 & 24 & 1.52 & $11.41^{* *}$ & -1.14 \\
\hline
\end{tabular}


fruits vine ${ }^{-1}$ ranged from -1.42 to $72.50 \%$ over better parent, -5.57 to $65.35 \%$ over standard check 1 and -2.42 to $70.75 \%$ over standard check 2 . In comparison of $\mathrm{F}_{1} \mathrm{~s}$, as many as 52 $\mathrm{F}_{1} \mathrm{~s}$ had positive heterosis over their respective better parent; $45 \mathrm{~F}_{1} \mathrm{~s}$ over standard check 1 and 50 hybrids over standard check 2. Majority of $F_{1} \mathrm{~s}$ has displayed heterobeltiosis and standard heterosis and it may be due to the gynoecious back ground, which bear more female flowers, thus resulting into more number of fruits plant ${ }^{-1}$. The present findings agree with Bairagi et al. (2002); Sudhakhar et al. (2005); Singh and Sharma (2006); Yadhav et al. (2008).

High marketable yield is the ultimate objective of a breeder. The variety with excellent quality and high disease resistance cannot be successfully accepted by growers until it will have a significantly high yield in comparison to existing variety. Heterosis for marketable yield vine ${ }^{-1}$ ranged from -6.97 to $91.63 \%$ over better parent, -14.21 to $79.91 \%$ over standard check 1 and -15.15 to $77.94 \%$ over standard check 2 . There was significant positive heterosis over better parent in 50 cross, 42 cross over standard check 1 and 41 crosses over standard check 2 . The hybrid vigour of these crosses for marketable yield may be attributed to their for increased fruit number, weight and fruit size. Heterosis for this trait has also been reported by Singh and Sharma (2006); Yadav et al. (2008); Hanchinamani and Patil (2009).

Duration in positive direction is desirable because more the duration more is the yield. The magnitude of heterosis for this trait over better parent, standard check 1 and standard check 2 varied from -18.89 to $15.59 \%,-10.31$ to $24.67 \%$ and -6.58 to $29.85 \%$, respectively. As many as 33 cross combinations exhibited hybrid vigour over better parent, 40 cross over standard check 1 and 43 cross over standard check 2 revealed hybrid vigour for harvest duration.

Relatively higher TSS is desirable in cucumber, since this may be associated with better taste and quality. The magnitude of heterosis for this trait (Table 2) varied from -11.40 to $25.29 \%$, -9.39 to $19.05 \%$ and -13.18 to $14.07 \%$ over better parent, standard check 1 and standard check 2 , respectively. Twenty nine crosses over better parent, fourty crosses over standard check 1 and twenty four crosses exhibited positive heterosis over standard check 2 .

On the basis of economic heterosis calculated over Solan Khira Hybrid-1 (SC1) and Pusa Sanyog (SC2), many crosses exhibited the presence of desirable heterotic response for different characters (Table 2). In order of merit, Plp $\times$ K-pap, G-3 $\times$ Sel-75-2-10 and G-1 $\times$ K-pap exhibited positive standard heterosis for marketable yield vine ${ }^{-1}$. Superiority of these crosses might be attributed to heteriobeltiosis of either parent and heterosis over standard checks for most of the characters in desirable direction.

\subsection{Pest and disease incidence}

Cucumber is attacked mainly by red pumpkin beetle, Aulacophora foveicollis (Lucas) during the early plant growth stages and later on its fruiting stage is ravaged by fruit flies, Bactrocera (Dacus) cucurbitae (Coquillett). The melon fly has a wide distribution throughout south-east Asia and attacks fruits of a wide range of plant species including vegetables, horticultural fruits and even beans (Narayan and Batra, 1960; Chawla, 1966; Syed, 1970). It causes severe damage to the crop which results in considerable reduction in yield and market value of the fruits (Srinivasan and Narayanswamy, 1961). According to Mote (1975), yield losses in India due to $B$. cucurbitae may be as high as $40-80 \%$. Nearly $50 \%$ of cucurbits are reported partially or completely damaged by the pest every year in India (Aggarwal et al., 1987). Findings of present study (Table 3) revelaed that cross combination G- $1 \times \mathrm{K}-75$ showed resistance to fruit fly incidence at Palampur in addition to EC-5082 $\times$ EC-173934, EC-5082 $\times \mathrm{K}-75$ and

Table 3: Crosses showing resistance against disease-pest over different locations

\begin{tabular}{|c|c|c|c|c|c|c|c|c|c|c|c|c|}
\hline \multirow[t]{3}{*}{ Genotypes } & \multicolumn{6}{|c|}{ Fruit fly infestation $(\%)$} & \multicolumn{6}{|c|}{ Powdery mildew incidence (\%) } \\
\hline & \multicolumn{3}{|c|}{ Palampur } & \multicolumn{3}{|c|}{ Bajaura } & \multicolumn{3}{|c|}{ Palampur } & \multicolumn{3}{|c|}{ Bajaura } \\
\hline & Cross & $\begin{array}{c}\text { Parent } \\
1\end{array}$ & $\begin{array}{c}\text { Parent } \\
2\end{array}$ & Cross & $\begin{array}{c}\text { Parent } \\
1\end{array}$ & $\begin{array}{c}\text { Parent } \\
2\end{array}$ & Cross & $\begin{array}{c}\text { Parent } \\
1\end{array}$ & $\begin{array}{c}\text { Parent } \\
2\end{array}$ & Cross & $\begin{array}{c}\text { Parent } \\
1\end{array}$ & $\begin{array}{c}\text { Parent } \\
2\end{array}$ \\
\hline EC- 5082×EC-173934 & MR & HS & HS & $\mathrm{S}$ & $\mathrm{S}$ & $\mathrm{S}$ & MS & $\mathrm{S}$ & MS & $\mathrm{S}$ & S & $\mathrm{S}$ \\
\hline EC-5082×K-75 & MR & HS & HS & S & S & HS & $\mathrm{S}$ & S & $\mathrm{S}$ & S & S & S \\
\hline Plp $\times$ K-pap & $\mathrm{S}$ & $\mathrm{S}$ & $\mathrm{S}$ & MR & $\mathrm{S}$ & $\mathrm{S}$ & $\mathrm{S}$ & $\mathrm{S}$ & $\mathrm{S}$ & $\mathrm{S}$ & S & $\mathrm{S}$ \\
\hline G-1×DPC-1 & MR & $\mathrm{s}$ & $\mathrm{S}$ & $\mathrm{S}$ & S & $\mathrm{S}$ & $\mathrm{S}$ & MS & MS & S & S & $\mathrm{S}$ \\
\hline G-1×K-75 & $\mathrm{R}$ & $\mathrm{S}$ & HS & MR & $\mathrm{S}$ & HS & $\mathrm{S}$ & MS & $\mathrm{S}$ & $\mathrm{S}$ & $\mathrm{S}$ & $\mathrm{S}$ \\
\hline G-3×K-pap & S & S & $\mathrm{S}$ & MR & S & $\mathrm{S}$ & MS & MR & $\mathrm{S}$ & MS & MS & $\mathrm{S}$ \\
\hline G-3×Poinsette & $\mathrm{S}$ & S & $\mathrm{S}$ & $\mathrm{S}$ & $\mathrm{S}$ & $\mathrm{S}$ & MR & MR & MR & MS & MS & MS \\
\hline G- $3 \times$ Sel-75-2-10 & MR & S & HS & MR & S & S & MS & MR & $\mathrm{S}$ & $\mathrm{S}$ & MS & $\mathrm{S}$ \\
\hline
\end{tabular}


G- $1 \times$ DPC- 1 were found to be moderately resistant therein whereas, Plp $\times$ K-pap, G-1 $\times$ K-75 and G-3 $\times$ K-pap were found to be moderately resistant crosses at Bajaura. G- $3 \times$ Sel-75-2-10 was moderately resistant to fruit fly incidence at both the locations. More interesting to note that these hybrids showed superiorty over its parents which showed susceptible at both the locations.

Cucumber is vulnerable to the attack of a number of fungal, bacterial and viral diseases of which powdery mildew, known to be caused by three pathogens viz., Sphaerotheca fuliginea, Erysiphe cichoracearum and Leveillula taurica the world over. In Himachal Pradesh, it has been observed to be one of the destructive disease causing severe damage to the foliage and reduce potential fruit yield considerably (Anonymous, 1996), from where only E. cichoracearum has been reported to be the causal agent of this disease (Sohi and Sharma, 1965). In the present investigation, majority of the cross combinations (Table 3) found succumb to this disease were susceptible. Only one cross combination G-3 $\times$ Poinsette was found to be moderately resistant at Palampur along with parents G-3 and Poinsette whereas, at Bajaura, the same cross combination and parents were moderately susceptible. Most of the crosses and parents gave susceptible reaction to this disease at both the locations.

\section{Conclusion}

The findings of investigation may be concluded with presence of considerable heterosis among crosses for most of the yield contributing traits over better parent, standard check 1 and standard check 2 . Of three superior crosses, Plp $\times$ K-pap may be commercially utilized as hybrid for early and high yield. However, cross G-3 $\times$ Sel-75-2-10 and G-3×Poinsette can be used to develop segregants for fruit fly and powdery mildew resistance.

\section{References}

Aggarwal, M.C., Sharma, D.O., Rahman, O., 1987. Melon fruit fly and its control. Indian Horticulture 32(2), 10-11.

Anonymous, 1996. Annual Report of the department of Mycology and Plant Pathology, Dr. Y.S. Parmar University of Horticulture and Forestry for the year 1995-1995.

Bairagi, S.K., Singh, D.K., Ram, H.H., 2002. Studies on heterosis for yield attributes in cucumber (Cucumis sativus L.). Vegetable Science 29(1), 75-77.

Cargill, B.F., Marshall, D.E., Levin, J.H., 1975. Harvesting cucumbers mechanically. Michigan University Extension Bulletin 47, E-859.

Chawla, S.S., 1966. Some critical observations of the biology of melon fly, Dacus cucurbitae coquillett (Diptera: Trypetidae). Research Bulletin Punjab University
Science 17, 105-107.

Cramer, C.S., Wehner, T.C., 1999. Little heterosis for yield and yield components in hybrid of six cucumber inbreds. Euphytica 110(2), 99-108.

Dhillon, N.P.S., 2004. Variation and genetics of tolerance to cull fruit formation in slicing cucumber. Plant breeding 123(4), 386-388.

El-Shawaf, I.I.S., Baker, L.R., 1981. Inheritance of parthenocarpic yield in gynoecious pickling cucumber for once-over mechanical harvest by diallel analysis of six gynoecious lines. Journal of the American Society of Horticultural Science 106(3), 359-64.

Gomez, K.A., Gomez, A.A., 1984. Statistical procedures for agricultural research. $2^{\text {nd }}$ Edn. John Willey and Sons, New York, 97-411.

Gopalakrishnan, T.R., 2007. Cucurbits. In: Vegetable Crops. New India Publishing Agency, New Delhi, 103-161.

Hanchinamani, C.N., Patil, M.G., 2009. Heterosis in cucumber (Cucumis sativus L.). Asian Journal of Horticulture 4(1), 21-24.

Hayes, H.K., Immer, F.F., Smith, D.C., 1956. Methods of plant breeding. McGraw Hill Book Publishing Company, Inc., New Delhi, 21-34.

Miller, J.C. Jr., Quisenberry, J.E., 1976. Inheritance of time to flowering and its relationship to crop maturity in cucumber. Journal of the American Society for Horticultural Science 101(4), 497-500.

Mote, O.N., 1975. Control of fruit fly (Dacus cucurtitae) on bitter gourd and cucumber. Pesticides, 9(8), 36-37.

Narayanan, E.S., Batra, H.N., 1960. Fruit flies and their control. Indian Council of Agricultural Research, New Delhi, 1-68.

Nath, P., 1966. Varietal resistance of gourds to fruit fly. Indian Journal of Horticulture 23(1-2), 69-78.

Pati, K., Munshi, D.A., Behera, K.T., 2015. Inheritance of gynoecism in cucumber (Cucumis sativus L.) using genotype GBS-1 as gynoecious parent. Genetika 47(1), 349-356.

Peterson, C.E., 1960. A gynoecious inbred line of cucumber. Mich. Agr. Expt. Sta. Quart. Bull. 43, 40-42. Cited from Plant Breeding Review, 6, Breeding for improved yield in cucumber, edited by Todd C. Wehner, 322-353.

Peterson, C.E., 1975. Plant introductions in the improvement of vegetable cultivars. Horticultural Science 10(6), 575-579.

Saikia, J., Shadique, A., Bora, G.C., 1995. Genetic studies in cucumber: 2. Heritability and genetic advance of yield components. Haryana Journal of Horticultural Sciences 24(1), 73-76.

Sen, B., Kapoor, I.J., 1974. Field trials of systemic and 
non-systemic fungicides against powdery mildew of cucurbits. Pesticides 8(4), 43-46.

Singh, Y., Sharma, S., 2006. Combining ability through line x tester analysis in cucumber (Cucumis sativus L.). Crop Research Hissar 31(1), 110-115.

Sohi, H.S., Sharma, S.L., 1965. Disease of crops, vegetables and subtropical fruits. Department of Agriculture, H.P. Farmers Bulletin 21, 34.

Srinivasan, P.M., Narayanaswamy, P.S., 1961. Appropriate time for taking up control measures against fruit flies on ash gourd (Benincasa cerefera L.) and pumpkin (Cucurbita moschata L.). Madras Agricultural Journal 48(8/10), 395-396.

Sudhakar, P., Singh, B., Major, S., Rai, M., 2005. Heterosis in cucumber (Cucumis sativus L.). Vegetable Science 32(2), 143-145.
Syed, R.A., 1970. Studies on the ecology of some important species of fruit flies and their natural enemies in West Pakistan. Pak. Common. Inst. Control. Stn. Rep. Rawalpindi. Farnhan Royal, Slough, UK. Common Agriculture Bulletin, 12.

Turner, J.M., 1953. A Study of heterosis in upland cotton II. Combining ability and inbreeding effects. Agronomy Journal 43, 487-490.

Wehner, T.C., 1987. Genotype-environment interaction for cucumber yield in 23 North Carolina environments. Cucurbit Genetics Cooperative Report 9, 47-50.

Yadav, J.R., Singh, S.P., Singh, N., Singh, P.B., 2008. Heterosis in cucumber (Cucumis sativus L.). Progressive Research 3(1), 87-88.

Yawalkar, K.S., 1985. Vegetable Crops of India. AgriHorticultural Publishing House, Nagpur, 300. 